\title{
Investigating Multiplicity: Institutional Logics and Division II Commuter Student Athletes
}

\author{
Jay Martyn ${ }^{1}$, Brent D. Oja², and Alan L. Morse ${ }^{2}$ \\ ${ }^{1}$ University of Colorado at Denver, ${ }^{2}$ University of Northern Colorado
}

\begin{abstract}
The primary purpose of this study was to examine the perceptions of commuter student athletes who were thought to experience a multiplicity of institutional logics while competing at the NCAA Division II level. Second, if multiple competing logics were present, the authors intended to test a theoretical model of logic multiplicity development. Utilizing a case study methodology, the authors collected data from commuter student athletes competing at the Division II level. The study's findings indicated that commuter student athletes perceived the presence of multiple competing logics and that these logics indicated an aligned or minimally estranged organization. In particular, the high compatibility and high centrality of multiple competing logics signified an organization aligned between academic, athletic, and family values, whereas the low centrality and low compatibility of social identification and societal factors denoted an estranged organization for commuter student athletes. The implications of this research within sport management are presented herein.
\end{abstract}

Keywords: Institutional Logics, Logic Multiplicity, Commuter Students, Compatibility, Centrality

\section{Introduction}

A review of the sport management literature indicated an increasing scholarly interest in the institutional logics perspective (Carlsson-Wall, Kraus, \& Messner, 2016; Cousens \& Slack, 2005; Gammelsaeter, 2010; Gammelsaeter \& Solenes, 2013; Gilmore, 2013; Martyn, Fowler, Kropp, Oja, \& Bass, 2019; Nagel, Schlesinger, Bayle, \& Giauque, 2015; Nite, 2017; Nite \& Naauright, 2019; Nite, Singer, \& Cunningham, 2013; Nite, Abiodun, \& Washington, 2019). Institutional logics is defined as "the socially constructed, historical patterns of material practices, assumptions, values, beliefs, and rules by which individuals produce and reproduce their material substance, organize time and space, and provide meaning to their social reality" (Thornton \& Ocasio, 1999, p. 804). Sport organizations offer suitable conditions to analyze institutional logics, as these organizations operate with a magnitude of values, goals, and expectations, many of which may compete against one anoth- 
er (Chelladurai, 1987; Trail \& Chelladurai, 2002; Washington \& Ventresca, 2008). Furthermore, Meyer and Rowan (1977) postulated that "institutional environments are often pluralistic ... [A]s a result, organizations in search of external support and stability incorporate all sorts of incompatible structural elements" (p. 356).

Within the institutionalized sport setting, intercollegiate athletics in the US offer a fitting context by which to study the institutional logics perspective (Nite et al., 2013). Frey (1994) suggested that "the athletic department exists under the umbrella of the university, yet its operation and goals are inconsistent with those of the larger organization" (p. 120). Furthermore, scholars have suggested that college athletics must operate within both an academic logic and a commercial logic (Schulman \& Bowen, 2001; Southall \& Nagel, 2010). In particular, a key principle of the institutional logics perspective is the understanding that logics develop both within and across multiple levels of an organization.

However, thus far, sport researchers have approached logics from a macro-perspective. Nite and colleagues (2013) found that the logics of a faith-based university and its athletic department did not align, and Carlsson-Wall et al. (2016) reported that logics may be compatible not only between the field and organization, but also between situations within an organization. Southall and Nagel (2008) highlighted competing logics between the educational and commercial activities of National Collegiate Athletic Association (NCAA) basketball. Lastly, Nite (2017) demonstrated how the NCAA utilized message framing to support institutional logics. Each of these studies, although advancing an understanding of logics pertaining to sport, lacked an emphasis on individuals in the field and their reliance on societal and institutional contexts. Thornton and Ocasio (2008) proposed that, "to understand individual and organizational behavior, it must be located in a societal and institutional context, and this institutional context both regularizes behavior and provides opportunity for agency and change" (p. 102). Therefore, the focus of this study is NCAA student athletes, specifically non-residential commuter student athletes, who may experience the competing logics associated with academics, athletics, and societal influences. This study highlights how such logics are experienced, perceived, and managed within and across multiple institutionalized forces.

Additionally, there is a scarcity of academic literature focusing on non-residential, commuter student athletes. However, non-residential student athletes are worthy of scholarly attention considering that of the 2,576 four-year institutions located in the US, 1,151 (45\%) are primarily non-residential (Carnegie Classification of Institutions, 2019). Furthermore, commuter students face challenges relating to multiple life roles (e.g., parenting, full-time employment, community engagement), have problems integrating with social support systems, and may not feel a sense of belonging to their respective institutions (c.f. Braxton, Hirschy, \& McClendon, 2004; Keeling, 1999; Tinto, 1975, 1985, 1993). Lastly, when considering the lack of literature focused on non-residential commuter athletes, it is important to note that commuting students "may represent a small percentage of students at a private, residential liberal arts college or the entire population of a community college or urban institution" (Jacoby, 2000, p. 5). Further, current trends suggest that commuter 
student proportions will continue to grow and become more diverse (Jacoby \& Garland, 2004).

The purpose of this research was to understand if non-residential, commuter student athletes experience and perceive competing logics (e.g., those associated with athletics, academics, commuting, work, family, etc.), and, if so, to determine if these competing logics influence their tenure as student athletes. Another function of the study was to answer the scholarly call of Besharov and Smith (2014), who proposed a theoretical framework for exploring organizations that embody multiple logics and implored scholars to test and extend their theoretical framework in additional settings. Thus, we intended to test this framework within the sport management setting. Finally, as there remains a dearth of scholarly information pertaining to non-residential, commuter student athletes, the final aim of this research is to generate additional scholarly interest in a less-explored component of intercollegiate athletics.

\section{Theoretical Framework}

The institutional logics perspective was developed from the underpinnings of scholarly work evaluating institutionalism (Berger \& Luckman, 1967; DiMaggio \& Powell, 1983; Meyer \& Rowan, 1977, Zucker, 1977), organizational environments (Salanick \& Pfeffer, 1978; Selznick, 1948, 1949, 1957), and social identity theory (Tajfel, 1974; Tajfel, Turner, Austin, \& Worchel, 1979). Institutional logics was introduced by Alford and Friedland (1985) to describe the contradictory practices and beliefs of institutions in western society. Jackall (1988) expanded the definition of institutional logics to include "the complicated, experientially constructed, and thereby contingent set of rules, premiums, and sanctions that men and women in particular contexts create and recreate in such a way that their behavior and accompanying perspective are to some extent regularized and predictable" (p. 112). Scott (1995) suggested a drawback of logics was focusing on singular and separate structural assumptions as coercive, normative, or cognitive pressures as proposed by DiMaggio and Powell (1983). In developing their definition of institutional logics, Thornton and Ocasio (1999) suggested the coercive, normative, and cognitive approaches must be integrated as one structural concept rather than separate, individualized entities. Furthermore, the authors advised that institutional logics must consider the link between individual agency and cognition, as well as socially constructed practices and rule structures (Thornton \& Ocasio, 1999). Despite the varying concepts of institutional logics described above, one core link between these seminal scholarly works remains true - that logics must be understood both at the individual and societal levels (Thornton \& Ocasio, 2008).

As institutional logics reflect the values, principles, and practices within an organization, these logics guide the actors' behaviors and ultimately predict success within a specific field (Friedland \& Ashford, 1991; Lounsbury \& Pollack, 2001; Nite, 2017; Nite \& Nauright, 2019; Nite et al., 2013; Skirstad \& Chelladurai, 2011; Southall, 2008; Thornton \& Ocasio, 2008; Thornton, Ocasio, \& Lounsbury, 2012; Washington \& Ventresca, 2004; Washington \& Patterson, 2011). Moreover, scholars have 
suggested that organizations are embedded in fields having diverse groups of stakeholders who may have competing or divergent sets of logics (Alvesson, 2002; Berger \& Luckman, 1967; Granovetter, 1985; Kraatz \& Block, 2008; Zukin\& DiMaggio, 1990). Berger and Luckman (1967) posited that, to understand the societal influence of organizations, one must recognize that individuals and organizations are embedded within specific social structures, and Granovetter (1985) proposed that individual choices and actions are constrained by the networks within which they are embedded. Expanding on the postulations of Berger and Luckman (1967) and Granovetter (1985), Zukin and DiMaggio (1990) speculated that embeddedness occurs through either cognitive, cultural, or political processes. Cognitive embeddedness refers to "the ways in which the structured regularities of mental processes limit the exercise of economic reasoning; cultural embeddedness is the role of shared collective understandings in shaping economic strategies or goals" (Zukin \& DiMaggio, 1990, p. 20) and political embeddedness is defined as "the manner in which economic institutions and decisions are shaped by a struggle for power that involves economic actors and nonmarket institutions" (Zukin \& DiMaggio, 1990, p. 20).

As logics become embedded within an institution, a key component to understanding the organization's logics is the development of a collective social identification (Thornton et al., 2012), defined as "part of an individual's self-concept which derives from his [sic] knowledge of his [sic] membership of a social group (or groups) together with the emotional significance attached to that membership" (Tajfel, 1974, p. 69). Institutional logics have been shown to exert a significant influence on actors when they identify with a collective social group (Brickson, 2000; Kelman, 2006; Polletta \& Jasper, 2001). Brickson (2000) proposed that individuals identifying with the social group to which they belong are likely to cooperate with that specific group, and Kelman (2006) indicated that actors who identify with a specific group are likely to abide by that group's norms and rules. Based on these scholarly assumptions, the combination of embeddedness and collective social identification will result in the development of an individual's logics.

As the institutional logics perspective is a metatheoretical framework used to analyze the interrelationships among institutions, individuals, and organizations within a social system (Thornton et al., 2012), multiple logics may be present and may compete for primacy (Herremans, Herschovis, \& Bertels, 2009; Mattingly \& Hall, 2008; Nite \& Nauright, 2019; Nite et al., 2013; Southall \& Nagel, 2010; Southall, Nagel, Amis, \& Southall, 2008; Washington \& Ventresca, 2008). Herremans et al. (2009) discussed how competing logics can influence the corporate environment, and Mattingly and Hall (2008) presented the competing logics of multiple stakeholders and the consequent challenges accompanying the decision-making process. Nite and Nauright (2019) reported that college administrators whom staff members accused of abuse were challenged by the values of the institution and of public opinion. Nite et al. (2013) postulated that the logics of a Christian university and its athletics department do not always align. These scholars concluded that the religious culture of the university often conflicted with the logics of winning and marketing for the athletics department and therefore, the logics of the institution appeared to contrast with 
their respective athletics department (Nite et al., 2013). Southall and Nagel (2008) highlighted the complexity of competing logics within women's college basketball, and Southall et al. (2008) suggested that the NCAA men's basketball tournament faces competing logics in its presentation of March Madness. Both of these studies indicated the NCAA focused on a commercial revenue generation logic, which may at times be in direct conflict to the educational logics of the organization. Lastly, Washington and Ventresca (2008) discussed the contradicting logics present in the formation of collegiate basketball in the US. They concluded that the NCAA utilized its power and logics to remove institutions from the schedule who did not adhere to NCAA guidelines. When considering the presence of multiple logics, scholars have posited that logics can co-exist until a dominant logic reigns supreme (DiMaggio, 1983) or a hybrid version of an existing logic is adopted (Glynn \& Lounsbury, 2005). Also, multiple logics can co-exist for an extended period of time (Lounsbury, 2007; Marquis \& Lounsbury, 2007; Reay \& Hinings, 2005). Although these studies demonstrated the presence of multiple competing institutional logics, all lacked a framework within which competing logics could be examined as "a theoretical puzzle" (Besharov \& Smith, 2014, p. 364).

Scholars have offered divergent conclusions about the processes that occur when multiple logics are present within a single organization. When evaluating the presence of multiple logics within organizations, researchers have suggested the occurrence of the following: contestation and conflict (Battilana \& Dorado, 2010; Zilber, 2002), coexistence (McPherson \& Sauder, 2013), logic blending (Binder, 2007), innovativeness (Jay, 2012; Kraats \& Block, 2008), organizational demise (Tracey, Phillips, \& Jarvis, 2011), or domination of a single logic with the others peripheral (Jones, Maoret, Massa, \& Svejenova, 2012). In an effort to establish a baseline for understanding multiple logics within an organization and to delineate the types of logic multiplicity within organizations, Besharov and Smith (2014) proposed a framework having logic compatibility and logic centrality as its key dimensions. According to Besharov and Smith, compatibility refers to "the extent to which the instantiations of logics imply consistent and reinforcing organizational actions," and centrality is considered "the degree to which multiple logics are each treated as equally valid and relevant in organizational functioning" (Besharov \& Smith, 2014, p. 370). Based on the degree of compatibility and centrality between multiple competing logics, Besharov and Smith (2014) suggested four ideal organizational types: contested, estranged, aligned, and dominant. However, the degree of centrality and compatibility to multiple logics has not been considered. Therefore, when considering the logic multiplicity of commuter student athletes, the compatibility and centrality of logics should result in a contested, estranged, aligned, or dominant ideal type (Besharov \& Smith, 2014).

In contested organizations,

low compatibility leads actors to confront and grapple with divergent goals, values, and identities, as well as different strategies and practices for achieving 
those goals. High centrality leads multiple logics to vie for dominance, with no clear guide between them (Besharov \& Smith, 2014, p. 371).

In an estranged organization,

low compatibility means that logics offer inconsistent implications for organizational action, leading actors to grapple with divergent goals and divergent means of achieving those goals. Unlike in contested organizations, however, low centrality leads one logic to exert primary influence over organizational functioning (Besharov \& Smith, 2014, p. 372).

For aligned organizations,

the instantiation of multiple logics involves high compatibility and high centrality. High compatibility leads actors to draw on logics that offer consistent implications for organizational action, and high centrality leads multiple logics to exert strong influence over organizational functioning (Besharov \& Smith, 2014, p. 373).

\section{Lastly, dominant organizations}

exhibit multiple logics that have high compatibility and low centrality. As in aligned organizations, high compatibility leads actors to draw on logics that imply consistent goals for organizational action. As in estranged organizations low centrality leads to core organizational features that reflect a single logic (Besharov \& Smith, 2014, p. 374).

In creating this framework, Besharov and Smith intended not only to understand if multiple logics can exist in an organization but also the levels of variation with which they do so.

Scholars within the sport sector (Carlsson-Wall et al., 2016; Nite et al., 2013; Washington \& Patterson, 2011; Washington \& Ventresca, 2008) have called for an increased focus into understanding how institutional logics develop. Furthermore, understanding how multiple logics relate to one another is vital to a richer understanding of the forces influencing organizations (c.f. Besharov \& Smith, 2014; Suddaby, 2010). Thus, the purposes of the current study are the following. The first was to understand if non-residential, commuter student athletes experience and perceive competing logics (e.g., athletics, academics, commuting, work, family, etc.) and, if so, to determine if these competing logics influence their experiences as a student athlete; second, utilizing the Besharov and Smith (2014) framework, determine how non-residential, commuter student athletes manage a multiplicity of logics (i.e., contested, estranged, aligned, or dominant); and, lastly, as there remains insufficient scholarly information pertaining to non-residential, commuter student athletes, the final aim of this research was to generate additional scholarly interest in a component of intercollegiate athletics that has been explored to a lesser extent. To advance an understanding of the presence and development of logic multiplicity and in an effort to further develop the literature relating to a lesser explored population of the 
sport community (i.e., commuter student athletes), the following research questions guided this inquiry:

RQ1. How do non-residential, commuter student athletes view a college environment that may have competing logics and do these logics influence their careers as student athletes?

RQ2. If logic multiplicity is present, how do logics develop (contested, estranged, aligned, or dominant) among non-residential, commuter student athletes?

\section{Methods}

To understand the logic multiplicity of non-residential, commuter student athletes, we utilized a qualitative case study design (Stake, 1995; VanWynsberghe \& Khan, 2007). Although findings from a case study are contextually bound (Stake, 2005), the results of this study provided insight into how non-residential, commuter student athletes perceived and developed in an environment where logic multiplicity was present. Furthermore, the results of this study may prove useful in similar settings or may be utilized for future hypothesis development, a key purpose for conducting case study research (Hodge \& Sharp, 2017).

\section{Participants}

Primary data for this case study were obtained through in-depth, semi-structured interviews with 11 commuter university athletes from multiple teams who competed at the NCAA Division II level. Data were collected, transcribed, and immediately assessed following each interview and additional data were collected, transcribed, and analyzed until no new information could be generated, or a point of data saturation was realized (O'Reilly \& Parker, 2013). The institution is located in a major metropolitan city in the Northwestern region of the US and no student housing is provided to the student body (see Table 1 below). The semi-structured nature of interviews allowed for follow-up questions and helped to produce deep and meaningful data (Kvale, 1996). Study participants were recruited through purposive sampling methods to ensure that all participants were full-time, non-residential student athletes. Additionally, Merriam and Tisdell (2016) suggested purposive sampling allows for the selection of individuals who are knowledgeable about or experience the phenomenon of interest. Furthermore, as noted by Bernard (2002), purposive sampling ensures participants were willing and available to discuss opinions in an expressive and articulate manner. Lastly, purposive sampling allowed for the selection of participants from a small pool of potential participants and provided the best chance to obtain rich and descriptive information on the research topic (Jones, 2015). 
Table 1

Participant Demographics

\begin{tabular}{cccc}
\hline Participant & Year & Gender & Sport \\
\hline Corey & Junior & Male & Soccer \\
Chris & Junior & Male & Basketball \\
Alex & Sophomore & Female & Softball \\
Devin & Sophomore & Female & Soccer \\
Bobbie & Freshman & Male & Baseball \\
Pat & Senior & Female & Track \& Cross \\
& & & Country \\
Jamie & Junior & Female & Basketball \\
Jordan & Senior & Female & Volleyball \\
Kelly & Junior & Male & Baseball \\
Parker & Sophomore & Male & Tennis \\
Peyton & Senior & Female & Golf \\
\hline
\end{tabular}

\section{Procedures}

Interviews for all participants were conducted via face-to-face interaction at a location agreed upon by both the participant and the researcher. For the participant interviews, we developed an interview guide tailored from a review of the extant scholarly research pertaining to institutional logics and focused on how logics were perceived and developed (Besharov \& Smith, 2014; Friedland \& Alford, 1991; Lounsbury \& Pollack, 2001; Thornton \& Ocasio, 1999, 2008; Thornton et al., 2012). Furthermore, the semi-structured nature of the interviews allowed each participant to provide additional follow-up information to ensure a rich data-collection process that fully addressed the purpose of the study (Lincoln \& Guba, 1985). Sample questions for the semi-structured interviews included the following: (a) What values have been instilled by your coaches, professors, and colleagues here at this institution?; (b) Are there certain behaviors you have to modify to adjust to the demands of academics?; (c) Do you feel you have to manage yourself differently in certain different situations, such as an athletic setting versus an academic setting versus a social setting?; (d) As a student athlete attending a commuter school, what are the most complex challenges you face? How do you successfully manage these challenges?; and (e) As a commuter student, what types of items do you have to balance in your life? Does this institution value your need to balance these items? Why or why not?

To ensure that the results of this case study were reliable and credible, a number of qualitative techniques were employed during the research process, including researcher transcriptions, member checking, and triangulation (Crotty, 1998). Additionally, all participants were provided a copy of their transcription, which had been transcribed verbatim from their audio-recorded interview to ensure an accurate 
portrayal of the data. To safeguard the trustworthiness of the research, we adhered to the principles of credibility, dependability, confirmability, transferability, and authenticity (Lincoln \& Guba, 1985). Credibility was achieved through methods such as member-checking, peer-debriefing, and reflective journaling. Dependability was accomplished by completing an audit trail, which could be followed by future researchers. Confirmability was ensured through the researchers' logs and audit trails, which allows for neutrality in the findings and replication of the study. The current study provided rich description of the participants, methods, and analysis procedures, which allows for the transferability of the results to a population in a similar setting. Lastly, authenticity was achieved as we realistically conveyed the data and were transparent about the analysis.

\section{Data Analysis}

The data were analyzed using a primarily deductive approach, as outlined by Braun and Clarke (2006). The analysis procedure consisted of six strands. To begin the analysis, the researchers immersed themselves in the data with multiple readings of the transcripts. An initial set of codes were developed (e.g., time management, athlete identity, lack of community, academics and athletics, employment requirements, family values, and metropolitan lifestyle) based on data gathered from the interviews and the theoretical framework (i.e., the institutional logics perspective). In strand three, we grouped the codes into an initial set of themes, and, in strand four, these themes were reviewed against scholarly works pertaining to institutional logics to confirm their congruence with the data. Subsequently, we reviewed and defined the final themes, and this review involved comparing and contrasting the themes with the theoretical framework of the institutional logics perspective. This strand resulted in three themes: an alignment between athletics and academics logics, the influence of family logics on commuter student athletes' logics, and the direct influence of societal factors and the lack of community on the logics of commuter student athletes. In the sixth strand of the analysis, we selected "vivid, compelling extract examples" (Braun \& Clarke, 2006, p. 87) to accentuate these themes. Through the process of data analysis, the research team was able to provide a depiction of how the multiplicity of institutional logics impacted non-residential, commuter student athletes.

\section{Results}

Our research team examined how logics developed (contested, estranged, aligned, or dominant) among non-residential, commuter student athletes. Generally, we discovered the presence of multiple logics including logics related to athletics, academics, family, social identity, and community engagement. Furthermore, we determined that commuter student athletes may operate in either an aligned (i.e., high compatibility and high centrality) or a marginally estranged (i.e., low compatibility and low centrality) environment. The interviews conducted for the current study led our research team to identify three distinct themes: an alignment between athletics and academics logics, the influence of family logics on commuter student athletes' log- 
ics, and the direct influence of societal factors and the lack of community on the logics of commuter student athletes. Figure 1 displays the progression of first order categories to second order themes to our final aggregated themes from the data. Below we discuss each of these themes in detail and provide contextual examples to support the findings.

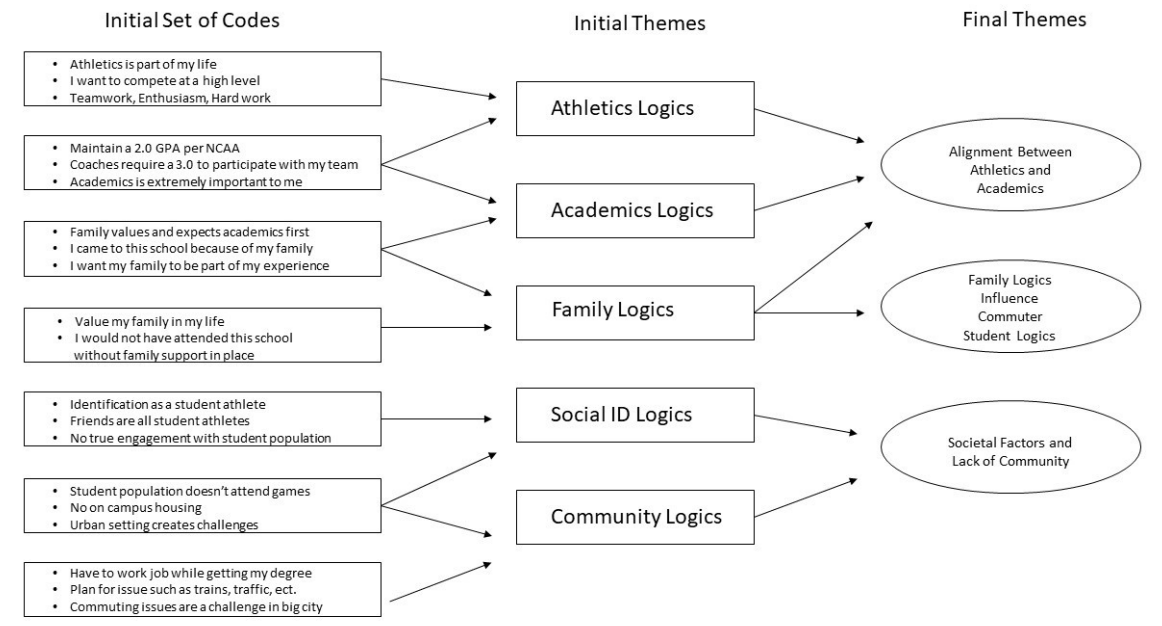

Figure 1: Data Structure

\section{An Alignment between Athletics and Academics}

We discovered that the logics of both academics and athletics appeared to align. In particular, all student athletes indicated that both the athletic department and their professors stressed the importance of such logics as "time management," "honesty," "integrity," and "respect." It appeared from the suggestions of the student athletes that, although coaches and professors did in fact operate in two distinct organizational environments, the logics instilled by their groups did align with high compatibility and high centrality. Moreover, all participants stressed the importance of achieving perfection both in the classroom and on the athletic field. Furthermore, the student athletes highlighted the significance of academic logics supporting and contributing to the athletics logics. According to nine participants, although the NCAA requires a minimum of a 2.0 grade point average to be eligible to compete in intercollegiate athletics, coaches required a minimum of a 3.0 for their student athletes. Furthermore, these nine participants indicated an alignment of athletic and academic logics through such contextual examples as their coaches emailing directly with their professors, mandatory academic sessions when traveling, and continued support of academics. Table 2 below provides contextual examples of alignments between athletic and academic logics. 
Table 2

Aligned Athletic \& Academic Logics Theme Quotations

\begin{tabular}{ll}
\hline Participant & \multicolumn{1}{c}{ Responses } \\
\hline Corey & My coaches honestly preach that you should be putting school \\
first. They constantly tell us we should have all A's and B's and \\
honestly, they won't even let us travel if you have a low GPA. \\
So, it really makes me work hard in class or I will miss out on \\
traveling and competing with my teammates. \\
My professors are really accommodating with my schedule. \\
They understand we need to travel, so if I am honest and up \\
front with them, they really will work with me. And my coach \\
told me from day one, to develop that personal relationship \\
with my professors, so we are all on the same page. \\
Our coach is really on top of our grades. I mean we have to \\
sign into her office for each of our study halls. And when we \\
travel on the weekends, I mean we play games on Friday and \\
Sunday, so Saturday she requires us to sit in a room at the \\
hotel and do our schoolwork. . It isn't an option. \\
Phris \\
I think first and foremost, being a student athlete means the \\
integration between academics and athletics and both being \\
mutually beneficial and symbiotic. My professors and coaches \\
have really helped me to become a better student and a better \\
runner at the same time. \\
Teamwork, enthusiasm, accountability, and mental toughness \\
were our team values this season. And in the classroom my \\
professors really push accountability, honesty, and integrity in \\
all your work. So, I think the message from both areas is really \\
similar.
\end{tabular}

\section{Family Logics Influence Commuter Student Logics}

The second theme, the influence of family logics on commuter student logics, was emphasized by all study participants. In fact, all of the commuter student athletes who were interviewed chose their institution because it valued and supported family logics. One specific international student athlete suggested that he came to the US because his parents valued getting an education while participating at a high level of athletic competition, something not available in their home country. Moreover, eight participants suggested that having a local family support system in place was an important part of deciding to attend a commuter school. These eight participants 
reported that their families attended both home and away games, that their families encouraged both athletics and academics, and that the locality of the institution provided an opportunity for student athletes to commute home when necessary. The study results indicated that the commuter student athletes looked for a high level of compatibility and centrality when selecting a school that would align with their family logics. Table 3 below offers contextual examples of family logics influencing commuter student logics.

Table 3

\section{Aligned Family Logics Influencing Commuter Student Theme Quotations}

\begin{tabular}{ll}
\hline Participant & \multicolumn{1}{c}{ Responses } \\
\hline Devin & $\begin{array}{l}\text { If I stayed in [home country], it was either soccer or an edu- } \\
\text { cation, but not both. My parents really pushed me to the idea } \\
\text { of playing in the US at a college because it was important to } \\
\text { them that I got an education and played soccer at a high level. } \\
\text { I never would have made that decision without my parents. } \\
\text { And now that I am here, I would do it 100 times again. } \\
\text { My mom is really important to me. I mean when I was a kid } \\
\text { my grades were really bad and she pulled me out of sports. } \\
\text { To this day, my grades are better because of that. I mean she } \\
\text { really made me realize that sports are important, but school is } \\
\text { equally as important as well. } \\
\text { I mean part of the reason I chose to come here versus a } \\
\text { campus away from home was so my family can come to my } \\
\text { matches. I mean my parents made every single home and } \\
\text { away match last season. My brothers come down and visit and } \\
\text { they are really supportive. Plus, I get to go home about once a } \\
\text { month during season and that is really important to me. } \\
\text { It was kind of challenging to come here because I am so far away } \\
\text { from my family. I mean they are a phone call away, but they } \\
\text { don't come to a lot of matches, and I mean family is important, } \\
\text { so I wish they were a little closer. But I still do my best in both } \\
\text { athletics and academics because it means so much to me and my } \\
\text { family too. }\end{array}$ \\
\hline
\end{tabular}

\section{Societal Factors and Lack of Community}

The logic multiplicity experienced by the student athletes participating in this study presented a somewhat highly aligned organization with high compatibility and high centrality. However, participants also indicated elements indicating an estranged organization with low compatibility and low centrality. All of the commuter student athletes indicated the low compatibility and low centrality for societal demands with 
which they were challenged. Specifically, all participants suggested that a lack of campus community impacted them as a student athlete because the campus community does not attend games. Oftentimes, these student athletes were required to have part-time jobs to support their education, a challenge to their time management skills. Furthermore, all student athletes suggested that time management was a requirement because they had to account for metropolitan traffic issues, parking concerns, or early morning practices. Additionally, two student athletes who previously attended residential campuses suggested that they could not just "roll out of bed and get to class or practice" but had to plan for train or bus schedules. All participant reports indicated that, although some of their intercollegiate experiences were aligned, others were marginally estranged within the institution. Table 4 below provides quotations describing the estrangement of the organization.

Table 4

Estranged Societal and Lack of Community Logics Influencing Commuter Students

\section{Theme Quotations}

\begin{tabular}{ll}
\hline Participant & \multicolumn{1}{c}{ Responses } \\
\hline Jamie & $\begin{array}{l}\text { Ya know, since we are located in a major city, there are a lot } \\
\text { of things to do down here. And I think that really hurts our } \\
\text { attendance at games. We don't get students to come and that is } \\
\text { tough because you really want to get some excitement around } \\
\text { what you're doing. So, it is really sad sometimes. }\end{array}$
\end{tabular}

Jordan

It is really tough because we live in such an expensive city and I have to work a part time job, well actually two, but I had to quit one for my internship. And you really have to manage your time to meet the expectations of professors, coaches, and your family. I might have to choose in the near future to drop something and it might be athletics, just because I have so much on my plate and I can't make everything work all at once.

Kelly

It is fun living in a big city, but it is also a challenge because I don't live on campus and I don't have a car. I can't be late for practice or class, so I have to rely on other people and I was not brought up that way. I am very independent and I hate depending on other people for rides, it goes against everything I was taught growing up.

Pat

I think one of the biggest challenges is that we don't have a track on campus. So, I constantly have to manage traffic to make sure I make it to practice on time. Plus, we can't have classes before 11:00 because we have weight training, so it is really hard to manage expectations and balance schoolwork, athletics, and getting time to sleep. It is really frustrating sometimes. 
Participants in the current study suggested that many of their personal logics did align with the logics instilled by their athletic and academic departments, suggesting a high level of compatibility and centrality residing within the intercollegiate institution. However, there did appear to be elements of an estranged organization for commuter student athletes as well, specifically with respect to societal demands and a lack of campus community. These results suggested possible low degrees of centrality and of compatibility in the logics of society and the campus community.

\section{Discussion}

The purpose of the current study was to understand how Division II commuter student athletes perceive and manage an environment where the presence of logic multiplicity may influence their academic and athletic careers. Moreover, Besharov and Smith (2014) proposed that, in the presence of logic multiplicity, these logics will result in either an aligned, estranged, dominant, or contested environment. Based on the postulations of Besharov and Smith, we utilized their model in an intercollegiate environment, where student athletes are possibly confronted with multiple and oftentimes competing logics. Participant responses indicated that the logics of this specific university did in fact have elements of high compatibility and high centrality, resulting in an aligned organization. However, discussions also highlighted elements of an estranged organization comprised of low compatibility and low centrality when student athlete relationships to the general student population and such societal demands as employment, commuting complications, and balancing multiple time requirements are considered. The results of the study provide insight into the multiplicity of logics NCAA student athletes experience and the challenges faced by a specific population (i.e., commuter student athletes) and demonstrate the applicability of the Besharov and Smith model.

The findings of this study contrast and expand upon the findings of previous researchers. Sport scholars have suggested a singular dominant logic is difficult to obtain in college sport (Frey, 1994; Nite et al., 2013; Southall \& Nagel, 2010) however, our results suggested that an alignment between logics is possible in the collegiate sport setting if both social groups value and identify with the organizations' institutional goals. The alignment of logics presented in this study appeared to be similar to Martyn et al. (2019) who reported NCAA Faculty Athletic Representatives, who are members of both the athletics and academics social groups, have an alignment of logics when facing a multiplicity of institutional logics. The current results advance the academic literature pertaining to institutional logics by focusing on the embedded actors who perceive and experience logics. Thus far, sport scholars have focused on the macro level of analysis and this study demonstrated logics can coexist as suggested by McPherson and Sauder (2013). It appears that the presence of multiple competing logics can result in an aligned organization where actors value and adopt a multiplicity of logics, as seen by coaches enforcing academic standards and professors valuing athletic participation, for all commuter student athletes. This 
alignment of logics experienced by student athletes appears to support Besharov and Smith's (2014) hypothetical model of organizational alignment in which multiple logics result in high compatibility and high centrality.

A second significant finding of this study was the influence of family logics on commuter student athletes. The scholars who proposed the institutional logics perspective have suggested that the concept of family is central to the development of one's logics (Thornton et al., 2012). Our results supported this proposition and demonstrated the importance of family in a commuter student athlete's logic development. Specifically, participants indicated that family values directly impacted their decision to attend this particular institution. Furthermore, family logics discussed by participants indicated the importance of success in the classroom and on the field. The suggestions put forth by our participants provide evidence for the influence of family logics on commuter student athletes. This finding could have significant bearing on understanding the logics of embedded actors within the NCAA, as much of the previous research has approached logics from a macro level approach. Our results provide a micro level approach to understanding institutional logics, and the influence of family on commuter student athletes' logic. Additionally, the findings related to family logics could be significant as commuter student athletes who have strong family logics are more committed to balancing a multiplicity of logics. The results of family logics influencing commuter student athletes furthers the institutional logics literature and offers a new avenue to explore this phenomenon in greater detail.

Although an alignment of logics was prevalent in the current study, there did appear to be some components of low centrality and low compatibility experienced by these commuter student athletes. Participants in this study suggested they do face societal struggles. Unlike traditional residential students, these commuter student athletes were required to manage unique societal demands (e.g., traffic, train schedules, off campus practices, lack of community engagement, etc.) which may not be experienced by a residential student athlete. Participants noted a lack of a sense of community on their campus. Moreover, participants indicated a strong sense of social identification with other student athletes, in which these athletes strongly identify with their collective group as opposed to the collective general student population. Our results represent the importance of social identities within institutional logics of the Division II setting and how a lack of identification can result in an estranged organization. Moreover, the collective identity of commuter student athletes appears to align with the suggestion of Polletta and Jasper (2001) that an emotional connectedness may develop due to the common status among that particular group. The results of this study suggested that commuter student athletes support each other due to the lack of support from the general student population. According to Besharov and Smith (2014), when low compatibility and low centrality among competing logics are present, one logic will exert primary influence over organizational functioning. The findings of this study indicated commuter student athletes associate with fellow student athletes because of their similar experiences and do not adhere to the social rules and norms of non-student-athletes. This finding may prove significant for a 
commuter institution because it appears that student athletes do not assimilate well with the general student population, essentially creating an us-versus-them mentality and possibly leading to challenges for campus administrators.

The findings of this study aligned with previous scholars who suggested that commuter students face challenges relating to multiple life roles (e.g., employment, community engagement), have problems integrating with social support systems, and may not feel a sense of belonging to their institutions (Braxton et al., 2004; Keeling, 1999; Tinto, 1975, 1985, 1993). As evidenced by the results of the current study, the low centrality and low compatibility of societal logics have a significant impact on a commuter student athletes' experience. Braxton et al. (2004) suggested commuter institutions lack structured social communities and the hurried nature of experience results in a lack of connection with the campus. Our results suggested one of the causes of disconnect lies in the lack of a social connection to the institution and general student population, and student athletes having to prioritize their schedules, goals, and values above social relationships and school work. This study advances knowledge pertaining to how commuter student athletes (i.e., actors) perceive societal logics and the impact societal logics have on those individuals, whereas others have focused on institutional norms, values, and goals. Furthermore, this study not only demonstrates the estrangement of logics, but also advances an understanding of the impacts of an organization with low compatibility and low centrality. This may prove significant because it appears that student athletes at commuter schools may withdraw from their athletic and academic commitments due to their societal requirements (e.g., employment, lack of identification, etc.).

The results of this study provided insight into the logics experienced by commuter student athletes and demonstrated how a multiplicity of logics established an aligned or semi-estranged organization on the campus. Scholarly attention should be attributed to commuter student athletes because almost half of college institutions in the US are primarily non-residential campuses (Carnegie Classification of Institutions, 2019). Furthermore, trends suggest that commuter student proportions will continue to grow and become more diverse (Jacoby \& Garland, 2004). If these trends are correct and commuter student populations continue to rise, scholars should look to address the changing society in college sport participation. The results of this study demonstrated that commuter student athletes lack an identification with the general population. Therefore, attention should be given to elements of the estranged organization where student athletes do not feel a belongingness to their institution. Moreover, this study highlighted the importance of the family logic on commuter student athletes. As evidenced by our findings, family logics strongly impact a commuter student athlete. This may indicate that institutions recruiting commuter student athletes, both academically and athletically, need to incorporate family logics into the decision-making process. The results of this study advance the literature relating to institutional logics, specifically pertaining to the importance of family logics. 


\section{Practical Implications}

The results of this study have multiple practical implications for the industry. First, the findings suggest that NCAA commuter student athletes perceive an aligned organization between academics and athletics due to practice and principles employed by coaches and professors. Athletic department administrators may employ similar tactics used by this institution's department to reinforce the academic standards of the whole institution. Second, commuter student athletes apparently do not identify with the student population of the commuter institution. Therefore, coaches and administrators may find contextual instances to incorporate student athletes into student body outings and the student body into athletic opportunities, thus making for a more unified campus despite the commuter style setting. Third, the significance of family logics could be utilized both for academic recruiting and athletic recruiting. If administrators understand commuter student athletes' family logics in greater depth, they may be able to recruit a higher quality student and athlete. Lastly, commuter student athletes are challenged with a magnitude of societal issues in their daily lives. If administrators, professors, and coaches understand the challenges associated with commuter student lives, they may be better able to incorporate a structure that is compatible with an environment containing a multiplicity of logics.

\section{Limitations and Future Research}

This study was not without limitations. The case study was bounded by time and space, and it therefore only provided the experience of a single institution. Also, this study captured the experiences of commuter student athletes and not a cross representation of athletic department managers and academic professors, and these viewpoints could provide further insight into commuter student athletes logics. Future research could continue to evaluate the perspective of commuter student athletes with regards to topics such as social identity, sense of community, belongingness, and other perspectives as these areas of scholarly research remain unexplored. The results of this study indicated that commuter student athletes do face issues such as identification and sense of community, and future research may shed light on these challenges experienced by commuter student athletes. Additionally, scholars could explore the experiences of commuter student athletes at the Division I, II, and III level as there may be contextual differences between these divisions, and future research could advance an understanding of these differences. Finally, scholars are encouraged to examine the institutional logics of NCAA actors from Division I, II, and III because while scholars have shown the presence of logics, there is a lack of an understanding of where and how logics develop. These logics could be examined from the student athlete, coach, mid-level employee, and athletics administrator level perspectives as an interinstitutional system encompassing these factors may reveal how logics form and are enforced by specific individuals. Results of future research could inform a deeper understanding of identification, culture, or other key factors of the metatheory of institutional logics. Thus far, academic inquiry has not focused on an interinstitutional system of logics, and a multi-level of analysis is necessary to explain the logic development of multiple actors operating within the NCAA framework. 


\section{References}

Alford, R. R., \& Friedland, R. (1985). Powers of theory: Capitalism, the state, and democracy. Garden City, NY: Cambridge University Press.

Alvesson, M. (2002). Postmodernism and social research. Buckingham: Open University Press.

Battilana, J., \& Dorado, S. (2010). Building sustainable hybrid organizations: The case of commercial microfinance organizations. Academy of Management Journal, 53(6), 1419-1440.

Berger, P. L., \& Luckmann, T. (1967). The social construction of reality: A treatise in the sociology of knowledge. Garden City, NY: Doubleday.

Bernard, H. R. (2002). Research methods in anthropology: Qualitative and quantitative approaches. Walnut Creek, CA: $3^{\text {rd }}$ Alta Mira Press.

Besharov, M. L., \& Smith, W. K. (2014). Multiple institutional logics in organizations: Explaining their varied nature and implications. Academy of Management Review, 39(3), 364-381.

Binder, A. (2007). For love and money: Organizations' creative responses to multiple environmental logics. Theory and Society, 36(6), 547-571.

Braun, V., \& Clarke, V. (2006). Using thematic analysis in psychology. Qualitative Research in Psychology, 3(2), 77-101.

Braxton, J. M., Hirschy, A. S., \& McClendon, S. A. (2004). Student departure in commuter colleges and universities. ASHE-ERIC Higher Education Report, $30(3), 35-51$.

Brickson, S. (2000). The impact of identity orientation on individual and organizational outcomes in demographically diverse settings. Academy of Management Review, 25(1), 82-101.

Carlsson-Wall, M., Kraus, K., \& Messner, M. (2016). Performance measurement systems and the enactment of different institutional logics: Insights from a football organization. Management Accounting Research, 32, 45-61.

Carnegie Classification Homepage (2019). The Carnegie Classification of Institutions of Higher Education 2018 Update Facts \& Figures. Retrieved from http:// carnegieclassifications.iu.edu/downloads/CCIHE2018-FactsFigures.pdf

Chelladurai, P. (1987). Multidimensionality and multiple perspectives of organizational effectiveness. Journal of Sport Management, 1(1), 37-47.

Cousens, L., \& Slack, T. (2005). Field-level change: The case of North American major league professional sport. Journal of Sport Management, 19(1), 13-42.

Crotty, M. (1998). The foundations of social research: Meaning and perspective in the research process. Thousand Oaks, CA: Sage.

DiMaggio, P. J., \& Powell, W. W. (1983). The iron cage revisited: Institutional isomorphism and collective rationality in organizational fields. American Sociological Review, 48, 147-160.

Frey, J. H. (1994). Deviance of organizational subunits: The case of college athletic departments. Journal of Sport and Social Issues, 18(2), 110-122. 
Friedland, R., \& Alford, R. R. (1991). Bringing society back in: Symbols, practices, and institutional contradictions. In W. W. Powell \& P. J. DiMaggio (Eds). The New Institutionalism in organizational analysis (pp. 232-263). Chicago, IL: University of Chicago Press.

Gammelsæter, H. (2010). Institutional pluralism and governance in "commercialized” sport clubs. European Sport Management Quarterly, 10(5), 569-594.

Gammelsæter, H., \& Solenes, O. (2013). Money in-brains out? Institutional logics affecting athletes' preparation for alternative careers. European Journal for Sport and Society, 10(3), 267-289.

Gilmore, S. (2013). Culture change in a professional sports team: Shaping environmental contexts and regulating power: A commentary. International Journal of Sports Science \& Coaching, 8(2), 305-307.

Glynn, M. A., \& Lounsbury, M. (2005). From the critics' corner: Logic blending, discursive change and authenticity in a cultural production system. Journal of Management Studies, 42(5), 1031-1055.

Granovetter, M. (1985). Economic action and social structure: The problem of embeddedness. American Journal of Sociology, 91(3), 481-510.

Herremans, I. M., Herschovis, M. S., \& Bertels, S. (2009). Leaders and laggards: The influence of competing logics on corporate environmental action. Journal of Business Ethics, 89(3), 449-472.

Hodge, K., \& Sharp, L.A. (2017). Case Studies. In B. Smith \& A.C. Sparkes (Eds). Handbook of Qualitative Research in Sport and Exercise (pp. 62-74). New York, NY: Routledge.

Jackall, R. (1988). Moral mazes: The world of corporate managers. New York: Oxford University Press.

Jacoby, B. (2000). Why involve commuter students in learning? New Directions for Higher Education, 109, 3-12.

Jacoby, B., \& Garland, J. (2004). Strategies for enhancing commuter student success. Journal of College Student Retention: Research, Theory \& Practice, 6(1), 61-79.

Jay, J. (2012). Navigating paradox as a mechanism of change and innovation in hybrid organizations. Academy of Management Journal, 56, 137-159.

Jones, I. (2015). Research methods for sports studies. New York, NY: Routledge.

Jones, C., Maoret, M., Massa, F. G., \& Svejenova, S. (2012). Rebels with a cause: Formation, contestation, and expansion of the de novo category "modern architecture," 1870-1975. Organization Science, 23(6), 1523-1545.

Keeling, R. P. (1999). A new definition of college emerges: Everything that happensto ... a (newly defined) student, in the context of a noisy visual dataspace. NASPA Forum, 20(5), 4-5.

Kelman, H. C. (2006). Interests, relationships, identities: Three central issues for individuals and groups in negotiating their social environment. Annual Review of Psychology, 57, 1-26.

Kraatz, M. S., \& Block, E. S. (2008). Organizational implications of institutional pluralism. In R. Greenwood, C. Oliver, K. Sahlin, \& R. Suddaby (Eds). The 
Sage handbook of organizational institutionalism (pp. 243-275). Thousand Oaks, CA: Sage.

Kvale, S. (1996). InterViews: An introduction to qualitive research interviewing. Thousand Oaks, CA: Sage.

Lincoln, Y.S., \& Guba, E.G. (1985). Naturalistic inquiry. Newbury Park, CA: Sage. Lounsbury, M. (2007). A tale of two cities: Competing logics and practice variation in the professionalizing of mutual funds. Academy of Management Journal, 50(2), 289-307.

Lounsbury, M., \& Pollack, S. (2001). Institutionalizing civic engagement: Shifting logics and the cultural repackaging of service-learning in US higher education. Organization, 8(2), 319-339.

Martyn, J., Fowler, B., Kropp, D. C., Oja, B. D., \& Bass, J. R. (2019). Managing an identity: Social identity complexity and NCAA faculty athletics representatives. Journal of Issues in Intercollegiate Athletics, 12, 365-383.

Marquis, C., \& Lounsbury, M. (2007). Vive la résistance: Competing logics and the consolidation of US community banking. Academy of Management Journal, 50(4), 799-820.

Mattingly, J. E., \& Hall, H. T. (2008). Who gets to decide? The role of institutional logics in shaping stakeholder politics and insurgency. Business and Society Review, 113(1), 63-89.

McPherson, C. M., \& Sauder, M. (2013). Logics in action: Managing institutional complexity in a drug court. Administrative Science Quarterly, 58(2), 165-196.

Merriam, S.B., \& Tisdell, E.J. (2016). Qualitative Research: A guide to design and implementation. San Francisco, CA: John Wiley \& Sons, Inc.

Meyer, J. W., \& Rowan, B. (1977). Institutionalized organizations: Formal structure as myth and ceremony. American Journal of Sociology, 83(2), 340-363.

Nagel, S., Schlesinger, T., Bayle, E., \& Giauque, D. (2015). Professionalization of sport federations-a multi-level framework for analyzing forms, causes and consequences. European Sport Management Quarterly, 15(4), 407-433.

Nite, C. (2017). Message framing as institutional maintenance: The National Collegiate Athletic Association's institutional work of addressing legitimate threats. Sport Management Review, 20(4), 338-351.

Nite, C., \& Nauright, J. (2019). Examining institutional work that perpetuates abuse in sport organizations. Sport Management Review, 23(1), 117-129. .

Nite, C., Abiodun, I., \& Washington, M. (2019). The evolving institutional work of the National Collegiate Athletic Association to maintain dominance in a fragmented field. Sport Management Review, 22(3), 379-394.

Nite, C., Singer, J. N., \& Cunningham, G. B. (2013). Addressing competing logics between the mission of a religious university and the demands of intercollegiate athletics. Sport Management Review, 16(4), 465-476.

O’Reilly, M., \& Parker, N. (2013). 'Unsatisfactory Saturation': A critical exploration of the notion of saturated sample sizes in qualitative research. Qualitative Research, 13(2), 190-197. 
Polletta, F., \& Jasper, J. M. (2001). Collective identity and social movements. Annual Review of Sociology, 27(1), 283-305.

Reay, T., \& Hinings, C. R. (2005). The recomposition of an organizational field: Health care in Alberta. Organization Studies, 26(3), 351-384.

Schulman, J. L., \& Bowen, W.G. (2001). The game of life: College sports and educational values. Princeton, NJ: Princeton University Press.

Scott, W. R. (1995). Institutions and organizations. Foundations for organizational science. London: A Sage Publication Series.

Salancik, G. R., \& Pfeffer, J. (1978). A social information processing approach to job attitudes and task design. Administrative Science Quarterly, 23(2) 224-253.

Selznick, P. (1948). Foundations of the theory of organization. American Sociological Review, 13(1), 25-35.

Selznick, P. (1949). TVA and the grass roots: A study in the sociology of formal organization. Berkley, CA: University of California Press.

Selznick, P. (1957). Leadership in administration. Berkeley, CA: University of California Press.

Skirstad, B., \& Chelladurai, P. (2011). For 'love' and money: A sports club's innovative response to multiple logics. Journal of Sport Management, 25(4), 339-353.

Southall, R. M., \& Nagel, M. S. (2008). A case-study analysis of NCAA Division I women's basketball tournament broadcasts: Educational or commercial activity? International Journal of Sport Communication, 1(4), 516-533.

Southall, R. M., \& Nagel, M.S. (2010). Institutional logics theory. In E. Smith (Ed.), Sociology of sport and social theory (pp. 67-80). Champaign, IL: Human Kinetics.

Southall, R. M., Nagel, M. S., Amis, J. M., \& Southall, C. (2008). A method to March madness? Institutional logics and the 2006 National Collegiate Athletic Association Division I men's basketball tournament. Journal of Sport Management, 22(6), 677-700.

Stake, R. E. (1995). The Art of case study research. Thousand Oaks, CA: Sage.

Suddaby, R. (2010). Challenges for institutional theory. Journal of Management Inquiry, 19(1), 14-20.

Tajfel, H. (1974). Social identity and intergroup behavior. International Social Science Council, 13(2), 65-93.

Tajfel, H., Turner, J. C., Austin, W. G., \& Worchel, S. (1979). An integrative theory of intergroup conflict. Organizational Identity: A reader, 56-65.

Thornton, P. H., \& Ocasio, W. (1999). Institutional logics and the historical contingency of power in organizations: Executive succession in the higher education publishing industry, 1958-1990. American Journal of Sociology, 105(3), 801-843.

Thornton, P. H., \& Ocasio, W. (2008). Institutional logics. In R. Greenwood, C. Oliver, K. Sahlin, \& R. Suddaby (Eds). The Sage handbook of organizational institutionalism (pp. 99-128). Thousand Oaks, CA: Sage.

Thornton, P. H., Ocasio, W., \& Lounsbury, M. (2012). The institutional logics perspective: A new approach to culture, structure, and process. Oxford, UK: Oxford University Press. 
Tinto, V. (1975). Dropout from higher education: A theoretical synthesis of recent research. Review of Educational Research, 45(1), 89-125.

Tinto, V. (1985). Dropping out and other forms of withdrawal from college. Increasing Student Retention, 2, 28-43.

Tinto, V. (1993). Building community. Liberal Education, 79(4), 16-21.

Tracey, P., Phillips, N., \& Jarvis, O. (2011). Bridging institutional entrepreneurship and the creation of new organizational forms: A multilevel model. Organization Science, 22(1), 60-80.

Trail, G., \& Chelladurai, P. (2002). Perceptions of intercollegiate athletic goals and processes: The influence of personal values. Journal of Sport Management, 16(4), 289-310.

Turner, J. C., Hogg, M. A., Oakes, P. J., Reicher, S. D., \& Wetherell, M. S. (1987). Rediscovering the social group: A self-categorization theory. Cambridge, MA: Basil Blackwell.

VanWynsberghe, R., \& Khan, S. (2007). Redefining case study. International Journal of Qualitative Methods, 6(2), 80-94.

Washington, M., \& Patterson, K. D. (2011). Hostile takeover or joint venture: Connections between institutional theory and sport management research. Sport Management Review, 14(1), 1-12.

Washington, M., \& Ventresca, M. J. (2004). How organizations change: The role of institutional support mechanisms in the incorporation of higher education visibility strategies, 1874-1995. Organization Science, 15(1), 82-97.

Washington, M., \& Ventresca, M. J. (2008). Institutional contradictions and struggles in the formation of US collegiate basketball, 1880-1938. Journal of Sport Management, 22(1), 30-49.

Zilber, T. B. (2002). Institutionalization as an interplay between actions, meanings, and actors: The case of a rape crisis center in Israel. Academy of Management Journal, 45(1), 234-254.

Zucker, L. G. (1977). The role of institutionalization in cultural persistence. American Sociological Review, 726-743.

Zukin, S., \& DiMaggio, P. (Eds.). (1990). Structures of capital: The social organization of the economy. New York, NY: Cambridge University Press. 